\title{
ITERATIVE REGULATION OF SECURITIES MARKETS AFTER BUSINESS ROUNDTABLE: A PRINCIPLES-BASED APPROACH
}

\author{
JAMES D. COX* \\ INTRODUCTION
}

It is hard to believe there is a Securities and Exchange Commission (SEC) regulation that has had greater impact than the antifraud provision, Rule 10b-5. The provision broadly proscribes any material misrepresentation or omission in connection with the purchase or sale of a security by "any means or instrumentality of interstate commerce." Due to its breadth, its impact is ubiquitous, stretching to include garden variety misrepresentations, ${ }^{2}$ broker misappropriation of customer funds, ${ }^{3}$ pump-and-dump schemes, ${ }^{4}$ failures to update public announcements, ${ }^{5}$ misstatements in proxy statements, ${ }^{6}$ and, of course, insider trading. ${ }^{7}$ Ambiguity regarding the rule's key components, such as what is a "misrepresentation," what is "material," and what facts establish the requisite scienter, ${ }^{10}$ are generally fact-specific, such that the rule's scope is

Copyright $\odot 2015$ by James D. Cox.

This article is also available at http://lcp.law.duke.edu/.

* Brainerd Currie Professor of Law, Duke University School of Law.

1. See 17 C.F.R. § 240.10b-5 (2014) (adopted pursuant to Securities Exchange Act of $1934 \S$ 10(b), 15 U.S.C. $\$ 78 j(b)(2012))$.

2. See, e.g., Dupuy v. Dupuy, 511 F.2d 641, 642 (5th Cir. 1975) (holding misrepresentation to have occurred in face-to-face dealings between family members of nonpublic company).

3. See, e.g., SEC v. Zandford, 535 U.S. 813, 821 (2002) (holding client was "duped into believing" his funds were being invested conservatively when in fact the broker was engaged in systematically embezzling funds generated by sales).

4. See, e.g., SEC v. Babikian, No. 14 Civ. 1740 (PAC), 2014 U.S. Dist. LEXIS 55678, at *1 (S.D.N.Y. Apr. 21, 2014).

5. See, e.g., Weiner v. Quaker Oats Co., 129 F.3d 310, 321 (3d Cir. 1997) (holding that a pending acquisition necessitated a duty to update regarding an earlier stated policy about debt-equity ratios that the company sought to maintain).

6. See, e.g., Vine v. Beneficial Fin. Co., 374 F.2d 627, 633 (2d Cir. 1967).

7. See infra notes 51-53 and accompanying text.

8. See, e.g., The Wharf (Holdings) Ltd. v. United Int'l Holdings, Inc., 532 U.S. 588, 596 (2001) (rejecting an argument that an omission was not a misrepresentation within the scope of the act because it did not involve the value of an underlying security).

9. See, e.g., Matrixx Initiatives, Inc. v. Siracusano, 131 S. Ct. 1309, 1312 (2011) (holding that a drug's possible danger to its users can be material despite the absence of statistically significant study indicating harm).

10. See e.g., SEC v. Falstaff Brewing Corp., 629 F.2d 62, 76 (D.C. Cir. 1980) (holding that scienter was met using facts that established that the defendant appreciated the misleading nature and 
inherently ambiguous, with the effect that fear of a potential violation elicits a good deal of precautionary behavior, especially for the more risk averse. Those who engage in securities-related transactions have genuine cause to fear that a disclosure gaff in connection with a business transaction could visit uncertainty, delay, and liability. Caution is further underscored by the reality that, not only are violations of Rule 10b-5 subject to enforcement efforts by the world's bestfunded securities regulator, but more significantly, private enforcement actions also exist.

Students of the history of Rule 10b-5 are well aware of the casualness by which the antifraud provision came into existence:

\begin{abstract}
I went to work one day in May, 1942, and I did my normal job as an Assistant Solicitor of the SEC. Somebody called me and said there is something wrong going on in Boston (a company president was buying in shares from his own shareholders without telling them of much improved earnings). He asked what we could do about it. I wasted no time; I got some people in, we drafted a rule, we presented it to the Commission, and, without any hesitation, the Commission tossed the paper on the table saying they were in favor of it. One Commission member said, "Well, we're against fraud, aren't we?" So, before the sun was down, we had the rule that is now Rule 10b-5. ${ }^{11}$
\end{abstract}

The casualness with which Rule 10b-5 was adopted reflects the very different regulatory era that existed in 1942; there was then no Administrative Procedure Act (APA). In contrast, agency rulemaking is presently conditioned not only on providing notice and opportunity for affected parties to comment, but also on ensuring that rulemaking, on review, not be arbitrary or capricious. ${ }^{12}$ Certainly the former was lacking during Rule 10b-5's genesis and we can only surmise (but with good cause for such surmise) the outcome with respect to the latter. If concern for the APA were not sufficient, then today's 800-pound gorilla in the rulemaking room is Business Roundtable $I I .{ }^{13}$ In a decision that likely ranks as the most significant decision in the history of the SEC, the D.C. Circuit struck down the SEC's adoption of a Rule 14a-11 that provided very limited rights for shareholders of reporting companies to nominate directors. ${ }^{14}$ In adopting the rule, the SEC was acting pursuant to the then-recently-enacted Dodd-Frank Wall Street Reform and Consumper Protection (Dodd-Frank) Act, which granted the Commission express power to adopt a rule providing shareholders authority to nominate directors. ${ }^{15}$ The benefits of providing such

consequences of statements).

11. Milton V. Freeman, Colloquium, Foreword, 61 FordHAM L. REV. S1, S1-S2 (1993).

12. See Administrative Procedure Act, 5 U.S.C. § 706(2)(A) (2012) (setting forth a general review standard of "arbitrary, capricious, an abuse of discretion, or otherwise not in accordance with the law").

13. Business Roundtable v. SEC, 647 F.3d 1144 (D.C. Cir. 2011) (Business Roundtable II).

14. The basic requirement was that nominations were limited to those (individually or collectively) that had held three percent of the voting shares for three years; such (a) holder(s) could nominate no more than one-fourth of the board seats and the provision could not be used by a holder seeking to change control or to gain a number of board positions in excess of the maximum permitted by the rule. 17 C.F.R. $\$ 240.14 a-11(b)(1)(2010)$.

15. Dodd-Frank Wall Street Reform and Consumer Protection Act, Pub. L. No. 111-203, § 971, 124 Stat. 1376, 1915 (2010) (adding Section 14(a)(2) to the Securities Exchange Act of 1934, 15 U.S.C. $\S$ $78 n(a)(2)(2012))$. 
access to shareholders had been a topic the SEC had studied for several years. ${ }^{16}$

Thus, looking back on the rainy afternoon, during far simpler times, when Rule 10b-5 was adopted, one might well conclude that Rule 10b-5 could never be adopted within the contemporary legal landscape. But, is this necessarily so? This article closely examines the limits of Business Roundtable II and, more specifically, sets forth one strategy that can be pursued in the present regulatory climate, in which cost-benefit analysis, although controversial-if not problematic_cannot presently be ignored.

THE READ OF THE COST-BENEFIT GREEN FOR SEC RULEMAKING

Business Roundtable II dramatically changed the regulatory gauntlet for the SEC. The historical irony is that this occurred over a matter that would have trivial effect on business, ${ }^{17}$ which therefore led to the ultimate irony: A case that chastised the SEC for failing to consider a cost-benefit calculation via close analysis, in reality, had little of either.

For several years, under pressure from the institutional investor community, the SEC had considered the desirability of amending the proxy rules to provide limited access to the nominating process for directors of reporting companies. The SEC did not act, however, largely because any rule would confront an earlier D.C. Circuit opinion, also brought by the Business Roundtable, holding that Section 14 of the Securities Exchange Act of 1934 (the Exchange Act) did not authorize the SEC to impose a one-share, one-vote requirement. ${ }^{18}$ Among the provisions included in the historic Dodd-Frank Act was the authority for the SEC to prescribe the procedure and conditions for such access. With lightning-like speed, the SEC adopted Rule 14a-11, which included a set of conditions that must be met for shareholder access. ${ }^{19}$ The conditions were such that the final rule was believed to be so narrow that no more than a handful of public companies in any year would be subject to shareholders invoking it. ${ }^{20}$ It

16. See, e.g., SEC, REVIEW OF THE Proxy Process REgarding THE NOMINATION AND ELECTION OF DIRECTORS (2003). Points that were not acknowledged and therefore not considered in Business Roundtable II were the weight, if any, to be given to the fact the SEC had for several years studied the question of shareholder access and, more fundamentally, that after such SEC consideration, Congress amended the Exchange Act to confer on the SEC authority for rules providing such access.

17. The sources of the rule's weaknesses were conditioning its application on the proponent or proponents being holders of three percent of the outstanding voting shares and then limiting nominations to no more than one-fourth of the total board seats. For a close analysis of the inconsequential effects of the ill-fated Rule 14a-11, see Marcel Kahan \& Edward Rock, The Insignificance of Proxy Access, 97 VA. L. REV. 1347 (2011).

18. See Business Roundtable v. SEC, 905 F.2d 406, 411 (D.C. Cir. 1990) (Business Roundtable I).

19. See Facilitating Shareholder Director Nominations, Exchange Act Release No. 9,136 (Aug. 25, 2010) (conditioning use of the rule, among other limitations, on the requirement that a proponent hold three percent or more of a reporting company's voting stock for at least three years in order to nominate only a small number of directors).

20. See Kahan \& Rock, supra note 17, at 1420-26 (close analysis of available data to conclude that the rule would have led to few actual nominations and those so nominated would likely be defeated). 
was over this mouse that the lion-like Business Roundtable II opinion roared, and with such ferocity that its resulting holding has impacted and retarded and, in some instances, has paralyzed SEC regulatory activity. Thus, the visible kill of the predatory business interests was small indeed, but it set the table for those interests to later enjoy future feasts.

The Business Roundtable II decision was a model of injudicious decisionmaking. ${ }^{21}$ First, at no point in his decision did Judge Douglas Ginsburg acknowledge that Dodd-Frank expressly authorized the SEC to provide rules for shareholder access to the proxy nominating process. The opinion frames the issue before the court on the propriety of an SEC rule providing shareholder access to the nominating process; Business Roundtable II did not focus on the specific conditions set forth in Rule 14a-11 that must be satisfied in order for a shareholder to invoke the benefits of the rule. Because Congress clearly empowered the SEC to exercise its administrative expertise to develop the process, it was unnecessary and inappropriate for the court to reconsider that policy issue. ${ }^{22}$ Congress, by expressly providing the SEC with authority to craft a rule providing access, took that general question off the table. That is, the D.C. Circuit had no greater authority to question this issue than it would have had if a challenge had been made regarding whether the bidder in a tender offer must disclose certain information prior to making its bid for shares. ${ }^{23}$

By not addressing the fact that Congress expressly empowered the SEC to issue rules providing shareholder access to the nomination process, Business Roundtable II overlooks a critical distinction between the Business Roundtable II decision and the Business Roundtable I decision where the D.C. Circuit struck down the SEC's effort to mandate one-share, one-vote for many public companies.

The Business Roundtable I decision was an instance that would have expanded the SEC's jurisdiction regarding the organic voting power of publicly traded shares. Since this was a matter solely of state concern, it became one of the grounds for declaring the SEC's regulation of supervoting shares an invalid exercise of power under Section 14 of the Exchange Act. As pointed out by a

21. It is not the purpose of this article to set forth the multiple failings of Business Roundtable II. A close examination of Judge Ginsburg's errors appears in James D. Cox \& Benjamin J.C. Baucom, The Emperor Has No Clothes: Confronting the D.C. Circuit's Usurpation of SEC Rulemaking Authority, 90 TEX. L. REV. 1811 (2012). The focus here is to develop one approach, among many, that can be pursued not only to address Business Roundtable II but to meet the ever-widening crowd of academics, policymakers, and practitioners who call for cost-benefit analysis of regulatory initiatives to have more empirical support of expected costs and related benefits believed to flow from the rule being proposed.

22. See Nat'l Ass'n of Mfrs. v. SEC, 748 F.3d 359, 370 (D.C. Cir. 2014) (in upholding the Commission's adoption of disclosure requirements with respect to whether issuer products included "conflict minerals," the court held it would have been inappropriate for the Commission to question the decision of Congress that "a disclosure regime would help promote peace and stability in the Congo").

23. See 15 U.S.C. $\S 78 \mathrm{n}(\mathrm{d})(1)$ (2012) (parallel to Section 14(a), making the commencement of certain tender offers unlawful without first filing information in connection with the tender offer's conduc that the SEC had authority to require). 
fellow contributor to this symposium, a hard look is much more justified in instances in which the effect of a rule is expanding an agency's turf. ${ }^{24}$ In contrast, the proxy access rule was preceded by an extension of the SEC's authority by Congress; it was not the SEC engaging alone to push regulation into a heretofore state-dominated area.

Thus, the court's focus should have been on the SEC's exercise of its regulatory power in establishing the conditions for such access. Indeed, the court studiously avoided even quoting the rule, let alone considering the benefits or burdens of each condition, or the conditions collectively. Because the grant of authority to the SEC is clear and unequivocal ${ }^{25}$ the focus of review should have been on the Commission's exercise of that authority in terms of the procedure, conditions, and resulting rights flowing from the rule. Because Business Roundtable II did not focus its review on how the SEC implemented the authority granted it by Dodd-Frank, the opinion is little less than a harangue on agency excess.

The most troubling feature of Business Roundtable II is that it ignores the clear meaning of the congressionally established review standards for SEC rulemaking and clear import of the legislative intent behind the review standards. The applicable review standard for SEC rules provides that, when "engaged in rulemaking," the SEC "is required to consider or determine whether an action is necessary or appropriate in the public interest" and "also consider, in addition to the protection of investors, whether the action will promote efficiency, competition, and capital formation." ${ }^{26}$

Business Roundtable II held that the SEC acted arbitrarily by failing to

24. Professor John Coates in this symposium persuasively makes the case that "hard look" review is especially justified as a means to address agency "empire-building," which occurs when agencies launch into heretofore unregulated areas, such as proxy access. See John C. Coates IV, Towards Better Cost-Benefit Analysis: An Essay On Regulatory Management, 78 LAW \& CONTEMP. PROBS., no. 3, 2015 at 1 . Professor Coates, while appearing to place proxy access into the "jurisdiction-expansion" realm for which heightened scrutiny is justified, does not consider in his analysis that Congress had empowered the SEC to enter this new area. Indeed, proxy access after Dodd-Frank appears consistent with Professor Coates's analysis of the SEC's actions regarding auditor assessment of management's internal control certifications after the enactment of Sarbanes-Oxley Act Section 404 mandating such assessments. Id. at 16-21.

25. There may have been some room for Judge Douglas Ginsburg's approach had Congress broadly empowered the SEC with authority "necessary and appropriate to enhance the role of shareholders in the election of directors." In that case, the broader inquiry into whether, among other alternatives (e.g., instead of the state statutory norm that director election occur by receipt of a plurality vote that directors not be elected unless they receive a majority of the votes cast), a rule providing shareholders the means to nominate directors could be open for discussion along the line taken in Business Roundtable II. Such consideration would be necessary to evaluate the choice that the SEC took (among many it could have taken) to act within the congressional authority "to enhance the role of shareholders in the election of directors." In contrast, Congress in Dodd-Frank narrowed the focus to providing "a requirement ... an issuer include a nominee submitted by a shareholder to serve on the board of directors of the issuer." Dodd-Frank Wall Street Reform and Consumer Protection Act, Pub. L. No. 111-203, § 971, 124 Stat. 1376, 1915 (2010).

26. 15 U.S.C. $\S 77 b(b)$ (2012); Securities Exchange Act of 1934, 15 U.S.C. $\S 78(c)$ (2012); Investment Company Act of 1940, 15 U.S.C. $\$ 80(a)$ (2012); Investment Advisers Act of 1940, 15 U.S.C. $\S 80($ b) (2012). 
weigh costs and benefits in connection with the "efficiency, competition and capital formation." 27 Judge Douglas Ginsburg would have benefited had he considered the source, and ultimately the meaning, of the quoted review standard. This portion of the review standard was added in 1996 by the National Securities Markets Improvement Act (NSMIA) to three of the four securities laws. ${ }^{28}$ The decision's error, however, is that the review standard does not require, with respect to any of these criterion, that the SEC determine or find that the adopted rule would "promote efficiency, competition, and capital formation"; instead, the review standard required only that the SEC consider the rule's effect in each of these areas. The SEC did so consider-in fact, as discussed earlier, the SEC had been considering for years the benefits of providing shareholder access to the nominating process for directors. Nonetheless, the D.C. Circuit did not believe those efforts were with the acuity and precision the court believed necessary. At several locations the opinion references assessments of costs and benefits. ${ }^{29}$

Various committee reports leading to Congress's enactment of the "promote efficiency, competition, and capital formation" criteria, while referencing the desirability of cost-benefit analysis in SEC rulemaking, nevertheless clearly rejected cost-benefit analysis as a formal standard. For example, cost-benefit analysis was included in the Senate's version of the legislation; the Senate's version, however, was not carried forward into NSMIA. ${ }^{30}$ Moreover, in 1999, when Congress ultimately extended the "promote efficiency, competition, and capital formation" language to the Investment Advisers Act, in the same legislation it amended the Commodity Futures Trading Act with very different language that unquestionably called for costbenefit analysis to support regulatory actions by the Commodity Futures Trading Commission (CFTC). ${ }^{31}$ As important as these considerations are, they were not part of the Judge Ginsburg's reasoning in Business Roundtable II.

Accordingly, Business Roundtable II rests on very problematic grounds. Nonetheless, that decision and other precedents that lurk within the SEC rulemaking jurisprudence, and more generally throughout contemporaneous

27. Business Roundtable v. SEC, 647 F.3d 1144, $1148-49$ (D.C. Cir. 2011) (Business Roundtable II).

28. For a close analysis of how the legislative history and more particularly the language employed by Congress in introducing the expanded review criteria in 1996 do not support Judge Ginsburg's reasoning, see generally James D. Cox \& Benjamin J.C. Baucom, The Emperor Has No Clothes: Confronting the D.C. Circuit's Usurpation of SEC Rulemaking Authority, 90 TEX. L. REV. 1811 (2012).

29. See, e.g., Business Roundtable II, 647 F.3d at 1150 (faulting SEC as it failed "to estimate and quantify the costs it expected companies to incur"); $i d$. at 1153 (rebuking the SEC for failing "in weighing the rule's costs and benefits" to consider the extent the new rule would "take the place of traditional proxy contests.").

30. See Cox \& Baucom, supra note 28, at 1819-20 (recounting how, in the legislative efforts leading to the 1996 broadening of the SEC's review standards, the Senate's effort was initially embodied in Senate Bill 1815, which clearly demanded cost-benefit analysis; however, this requirement vanished after the competing House and Senate bills were reconciled in conference).

31. See Gramm-Leach-Bliley Financial Modernization Act, Pub. L. No. 106-102, § 224, 13 Stat. 1338, 1402 (1999). 
regulatory setting, have the following operative impact: "hard look" review compels agencies such as the SEC to undertake efforts at precision and acuity that are indistinguishable from rigorous cost-benefit analysis. Business Roundtable II gives testament that this is a high standard, fraught with the potential for second-guessing by the judiciary and more so by a panel hostile to the broad objectives Congress sought to advance by empowering the agency to act.

\section{III}

\section{CORRELATION VERSUS CAUSATION}

Despite the multiple grounds for believing Business Roundtable II was wrongly decided and that cost-benefit analysis is not required for SEC rulemaking, regulators should nonetheless appreciate that formulation of sound policy requires a process that at least mimics cost-benefit analysis. Among the objectives of this message is that, when proposing a rule, the agency should seek to include among its inputs systematic and transparent efforts to minimize its burdens and maximize its benefits. Moreover, the contemporary political climate clearly anticipates that regulators will reduce regulatory burdens relative to the benefits sought. Thus, the scorching rhetoric of Business Roundtable II houses a truism that a close assessment of the costs and benefits matter a good deal in the sound formulation of policy.

The challenge for the SEC in meeting this expectation is perhaps greater than that faced by sister agencies, where benefits are not only somewhat easier to measure, but where the costs and benefits are also easier to associate with the regulatory change. ${ }^{32}$ To illustrate, consider the complaint that the SarbanesOxley Act of 2002 (SOX) reduced initial public offerings (IPOs), drove foreign issuers away from U.S. capital markets, and caused domestic companies to go private or dark (and thereby avoid increased regulation that SOX imposed on reporting companies). Each of these correlates to some degree with the enactment of SOX. But if this were the test, then, as was stated years ago in connection with an observation that older men were frequent patrons of burlesque shows, burlesque causes baldness.

To be sure, there was indeed an upwards spike in going private and going dark in the years surrounding SOX's enactment. But it was also a time when interest rates began to decline so that restructuring, and particularly private equity, were not just profitable but were thriving. To isolate causality between SOX and the reduction in the number of reporting companies necessarily

32. See John C. Coates IV, Cost-Benefit Analysis of Financial Regulation, 124 YALE L.J. 882 (2015) (arguing that financial regulation poses unique degrees of complexity due to its constructed and integrated nature that renders cost-benefit analysis problematic); Jeffrey N. Gordon, The Empty Call for Benefit-Cost Analysis in Financial Regulation, (Columbia Law Sch. Ctr. for Law and Econ. Studies, Working paper No. 464, 2013) (describing finance as a constructed system-due to its existence being the product of financial regulation - such that changes in the regulatory quilt necessarily produce a very different system that is harder to foresee than more scientifically bound systems from which costbenefit analysis has sprung, albeit with questionable predictive results). 
requires simultaneously isolating the effects of lower interest rates on the behavior of investment bankers seeking high returns through financial engineering. For example, the causal connection to SOX is greatly reduced by evidence that, during this same period, buyouts were occurring at about same pace in the United Kingdom-beyond the reach of SOX. ${ }^{33}$ In addition to falling interest rates, a further conflicting variable is the exuberance of the earlier dotcom market. The hot IPO market of the late 1990s is now understood to have prompted many companies to go public, only to retreat when markets and their share prices collapsed in 2002, raising the question of whether continued public status was worth the commensurate burdens.

Professors John Coates and Suraj Srinivasan provide an insightful assessment of the extensive empirical research on SOX's impact. ${ }^{34}$ The studies they review, while measuring the consequences of congressional initiatives that regulators considered in their own regulations, nonetheless reflect the above concern: it is much easier to identify and measure direct costs associated with a regulatory initiative than it is to identify and measure an initiative's benefits or indirect costs. To illustrate this point, consider the most controversial provision of SOX, the infamous Section 404(b), which calls for auditors to attest to management's certification with respect to whether material deficiencies exist in the firm's internal controls.

Section 404(b) quickly became the lightning rod for business outcry against SOX. Whereas the SEC estimated average compliance cost per issuer of $\$ 91,000,{ }^{35}$ experience gathered from a sample of Fortune 1000 companies reported average costs to comply with the internal control requirement was $\$ 5.9$ million. ${ }^{36}$ The Section 404(b) compliance costs were significantly greater in the initial years than in later years, ${ }^{37}$ reflecting a combination of deferred

33. See Christian Leuz, Was the Sarbanes-Oxley Act of 2002 Really this Costly? A Discussion of Evidence from Event Returns and Going-Private Decisions, 44 J. ACCT. \& ECON. 146, 162 (2007). Further persuasive evidence is produced by Robert P. Bartlett III, Going Private but Staying Public: Reexamining the Effect of Sarbanes-Oxley on Firms' Going-Private Decisions, 76 U. CHI. L. REV. 7, 3738 (2009) (observing that reporting costs are a major concern for small firms going dark, but not for medium or larger firms for whom debt issued pursuant to the transaction triggers ongoing reporting status).

34. See generally John C. Coates \& Suraj Srinivasan, SOX after Ten Years: A Multidisciplinary Review, 28 ACCT. HORIZONS 627 (2014).

35. Final Rule: Management's Report on Internal Controls Over Financial Reporting and Certification of Disclosure in Exchange Act Periodic Reports, Securities Act Release No. 8,238, Exchange Act Release No. 47,986, Investment Company Act Release No. 26,068, 80 SEC Docket 1,014 (June 5, 2003).

36. Charles River Assocs., Sarbanes-OXley Section 404 Costs AND Remediation of DEFICIENCIES: ESTIMATES FROM A SAMPLE OF FORTUNE 1000 COMPANIES 2 (2005).

37. U.S. GOV'T ACCOUNTABILITY OFFICE, GAO-06-361, SARBANES-OXLEY ACT: CONSIDERATION OF KEY PRINCIPLES NEEDED IN ADDRESSING IMPLEMENTATION FOR SMALLER Public COMPANIES, 16 Fig.1, 38 Tbl.4 (2006); SEC, StUdy OF THE SARBANES-OXLEY ACT OF 2002 SECTION 404 INTERNAL CONTROL OVER FINANCIAL REPORTING REQUIREMENTS (2009) (companies with revenues exceeding $\$ 5$ billion spent $0.06 \%$ of their revenues on SOX compliance, whereas companies with less than $\$ 100$ million in revenue spent $2.55 \%$; in 2004 , these costs represented about $40 \%$ of total audit fees, but declined to $32.5 \%$ in 2007). 
maintenance on reporting systems, a costly learning curve by both auditors and their clients, and a broad directive issued by the Public Company Accounting Oversight Board (PCAOB) that had been established by SOX to establish auditing standards and procedures for public companies. ${ }^{38}$ Particularly disquieting was that available data reflected that compliance with Section 404(b) disproportionately burdened smaller issuers; issuers with a market capitalization of less than $\$ 75$ million reported costs to implement the internal controls requirement represented 1.14 percent of annual revenues in 2003 and 2004 , whereas firms with a market capitalization above $\$ 1$ billion incurred compliance cost that represented 0.13 percent of revenues. ${ }^{39}$ Thus, the costs of implementing the new reporting requirement were substantial and poorly estimated by the adopting agency. ${ }^{40}$

The calculus on Section 404(b)'s benefits is more positive; but after all, this characteristic is the nature of benefits. However, ex ante as well as ex post benefits were neither easily estimated nor easily measurable. For example, financial restatements that were rising in the years immediately preceding SOX accelerated in the post-SOX years, peaking in 2006 and declining thereafter. The decline was as steep as the disturbing rise in restatements. ${ }^{41}$

Restatements document the error of earlier reports so that their presence can reflect weaknesses in earlier reporting systems - thus, a reduced number of restatements can be thought to be the result of improved reporting. Even if this thesis that the frequency of restatements is a reflection of improvement in financial reporting is accepted, the case for the benefits of Section 404(b) remains problematic. Because restatements were on the rise prior to SOX's enactment, it could be argued that implementation of Section 404(b) was without causal affect. To be sure, restatements accelerated after Section 404(b) went into effect, but it is possible that the forces that stimulated discovery of restatements prior to the implementation of Section 404(b) gathered strength over time. Moreover, there were other provisions in SOX itself that could have contributed to the detection of pre-SOX reporting errors that were corrected in SOX's wake. After SOX, accountants became more independent as three of the

38. See generally Joseph A. Grundfest \& Steven E. Bochner, Fixing 404, 105 MICH. L. REV. 1643 (2007).

39. Not to be missed is the selection bias with respect to reported costs of smaller issuers. Because of the firestorm that greeted Section 404(b) and the likely impact compliance with the provision would have on smaller issuers, the SEC granted a series of delays to its implementation for nonaccelerated filers (e.g., reporting companies with a market capitalization of less than $\$ 75$ million). Thus, those who did comply were likely companies who believed their reporting system did not contain material internal control weaknesses. Thus, their compliance costs could be expected to be lower than the average for their smaller issuer cohort.

40. It should be understood that Congress mandated attestation of internal controls, leaving it to the SEC and newly created PCAOB to implement the mandate. This factor likely does not explain the unforeseen costs of the mandate.

41. See Audit Analytics, 2009 Financial Restatements: A Nine Year Comparison 18 (2010); see also SusAn SCHOlZ, DeP'T OF TREASURY, THE Changing NATURE AND CONSEQUENCES OF PUBLIC COMPANY FINANCIAL RESTATEMENTS: 1997-2006 10-13 (2008). 
Big Four auditing firms divested their consulting business, and SOX broadly prohibited auditors from providing a range of business services to audit clients. ${ }^{42}$ Furthermore, SOX and listing requirements changed the composition of the audit committee so that the committee would be not only more independent of management but also made up of individuals better attuned to discharging the role of the audit committee. ${ }^{43}$

Mandated audit partner rotations, ${ }^{44}$ whistleblower hotlines ${ }^{45}$ and requisite periodic inspections by the Public Company Accounting Oversight Board (PCAOB) ${ }^{46}$ in combination, forced greater independence on the part of the auditing firms and, thus, could have had their own effect on unearthing and reporting restatements. Just which of these initiatives, including Section 404(b), or what combination of them, produced the reduction in restatements?

Further confounding the causal calculation is that, after 2007, the earlier internal control procedures for implementing Section 404(b) that were embodied in PCAOB Auditing Standard (AS) No. $2^{47}$ were replaced by AS No. $5 ;^{48}$ the former was much more inclusive, whereas AS No. 5 is principles-based, so that auditors enjoy greater discretion in attesting to management's assessment of internal controls. ${ }^{49}$ Most importantly, the new standard allows greater judgment to be exercised in carrying out the evaluation, allowing the auditor to scale its review.

The new auditing standard complicates the causality of Section 404(b). Without the new auditing standard, the question was complicated enough in isolating the decline in restatements (the surrogate for assessing overall quality of financial reporting) from declines caused by other developments that can be seen as strengthening financial reporting. With a new auditing standard believed to weaken implementation of Section 404(b), the question is whether the decline in restatements is the product of any of the SOX provisions or simply the new variable, AS No. 5. That is, against these variables, there are two possible but conflicting interpretations of the post-SOX experiences centered on restatements. One view is that the more relaxed, less formal auditing

42. See Securities Exchange Act of 1934, 15 U.S.C. § 78j-1(g) (2012).

43. See James D. Cox, Robert W. Hillman \& Donald C. Langevoort, Securities REGULATIONS: CASES AND MATERIALS 600-04 (7th ed. 2013).

44. See Securities Exchange Act of 1934, 15 U.S.C. § 78j-1(j) (2012).

45. See Securities Exchange Act of 1934, 15 U.S.C. $\$ 78 j-1(m)(4)$ (2012).

46. See Sarbanes-Oxley Act of 2002, Pub. L. No. 107-204, § 104, 116 Stat. 745, 757-59 (2002). At least equally important, Section 101 established an independent body to both promulgate and enforce standard operating procedures that auditors must follow in the conduct of their attestation with respect to reporting companies.

47. See Auditing Standard No. 2: An Audit of Internal Control Over Financial Reporting Performed in Conjunction With an Audit of Financial Statements (June 17, 2004), available at http://pcaobus.org/standards/auditing/pages/auditing_standard_2.aspx.

48. See Auditing Standard No. 5: An Audit of Internal Control Over Financial Reporting That Is Integrated with An Audit of Financial Statements (July 27, 2007), available at http://pcaobus.org/Standards/Auditing/Pages/Auditing_Standard_5.aspx.

49. See generally Robert R. MOELlER, SARBANES-OXLEy INTERNAL CONTROLS: EFFECTIVE AUDITING WITH AS5, COBIT, AND ITIL ch. 3 (2008). 
standard nonetheless fulfills the goals of Section 404(b) so that financial reporting is more trustworthy because of the auditor attestation. Alternatively, there is the view that the new auditing standard weakens Section 404(b)'s impact and, in turn, weakens the quality of financial reporting; but this view makes the case that Section 404(b), if wisely implemented, improves financial reporting.

The implication of the above is, as concluded by Professors Coates and Srinivasan, direct costs of a regulation can be determined, at least ex post; however, isolating and measuring benefits are much more problematic in part because of the difficulty of establishing causality. That difficulty is heightened in the instance of financial regulation because of the interconnectedness of financial regulation. The markets are what society made them to be through regulations that are interdependent; that is, markets reflect a web of regulation so that, when a new regulation is written and its likely impact is to be assessed, it must occur with a conscious regard for the web into which the new regulatory initiative will be inserted. Ex ante, the problems of assessing costs and benefits must be understood to be not just greater but fraught with judgments, assumptions, and estimates that challenge the efficacy of the process. In a sense, this problem is similar to a core complaint leveled against financial reporting itself: the bedrock of financial reporting are the metrics of generally accepted accounting principles, the application of which to a firm rests on scores of judgments, assumptions, and estimates. Thus, financial reports of firms that are intrinsically mirror images of one another can vary widely depending on the particular constellation of judgments, assumptions, and estimates that are made. In that sphere, the financial reports are not deemed misleading or even incorrect if the process that expressly includes discretion is adhered to by the preparers of the reports. As reasoned above, the APA's arbitrary and capricious standard, and particularly the operative verb "consider," in the SEC's review standard rightly direct attention not on finite evidence supporting a finding that measureable benefits exceed measurable costs. Rather, what is required of the SEC is a thoughtful and deliberate process whereby it considers means to maximize expected benefits while minimizing expected costs.

\section{IV}

\section{REGULATION BY ENFORCEMENT}

Although it is correct to say that Business Roundtable II imposes a significant restraint on SEC rulemaking, it is not correct to conclude that the decision has the same degree of restraint on the SEC as a regulator. This is because much of the regulation of the SEC has occurred not through rulemaking but through its robust enforcement efforts to which the earlierdiscussed review standards do not apply. In response to testimony given by then-SEC Chairman Arthur Levitt, Congress rephrased the House bill's 
language to clarify that the review standard applied only to "rulemaking.",50

The most dramatic illustration of how regulation of capital markets occurs through enforcement is the fulsome body of law on inside trading. In re Cady, Roberts \& Co. ${ }^{51}$ an SEC enforcement proceeding against a broker-dealer, was quickly followed by the landmark SEC v. Texas Gulf Sulphur Co. ${ }^{52}$ and now, a trilogy of Supreme Court decisions establish the regulatory web for inside trading. ${ }^{53}$ Their highly nuanced body of directives addresses a range of issues, including defining "wrongful trading," "tipping," and "misappropriation." Despite continuing debate on the social welfare of insider trading, the prohibitions for insider trading are no less effective because they were developed through litigation rather than rulemaking.

More generally, even though the SEC has resorted to Exchange Act Section 10(b) for authority to adopt intricate rules regulating a variety of market conduct, ${ }^{54}$ the most significant impacts of the antifraud provision are a consequence of the principles established through public and private suits founded on the principles embodied in Rule 10b-5 itself. ${ }^{55}$ Similarly, litigation has greatly informed the boundaries of the private offering exemption, discussed below. A current illustration of the use of enforcement to develop standards of conduct is the stepped-up enforcement actions by the SEC defining the boundaries of the duty of broker-dealers to supervise subordinates.

It is therefore possible, through enforcement of existing general proscriptions of fraud, such as Rule 10b-5, to regulate conduct and for the SEC to do this without encountering the burdens of the review standards. Nonetheless, the enforcement actions must be true to the principles underlying

50. See Capital Markets Deregulation and Liberalization Act of 1995: Hearings Before the Subcomm. on Telecomms. and Fin. of the H. Comm. on Commerce, 104th Cong. 110-11 (1996).

51. 40 S.E.C. 907 (1961).

52. 401 F.2d 833 (2d Cir. 1969) (en banc).

53. See United States v. O'Hagan, 521 U.S. 642, 665-66 (1997) (misappropriation of information can be the basis of a violation); Dirks v. SEC, 463 U.S. 646, 660 (1983) (tippers and their tippees commit insider trading when they are aware that the tip was in breach of an underlying fiduciary duty); Chiarella v. United States, 445 U.S. 222, 235 (1980) (the sine qua non for any violation is a fiduciary duty with respect to use of the information).

54. See, e.g., Rule 10b-10, 17 C.F.R. § 240.10b-10 (2014) (regulating the content of trade confirmations); Rule 10b-17, 17 C.F.R. $§ 240.10 b-17$ (2014) (timely notice of record dates related to certain corporate actions, such as dividend declarations); Regulation M, 17 C.F.R. $\S 242.100$ et. seq. (2014) (the so-called distribution rules regulating such conduct as purchases during a distribution as well as certain short selling).

55. For example, an overarching concern for all companies, public and private, is whether there is a duty to disclose information known to be material. Case law that has accreted overtime around Rule 10b-5 establishes the boundaries of such a disclosure duty. See, e.g., Donald C. Langevoort, HalfTruths: Protecting Mistaken Inferences by Investors and Others, 52 STAN. L. REV. 87 (1999). More generally, most of the jurisprudence defining materiality, a threshold consideration not only with the obligation to disclose under the antifraud provision as well as many directives for filings with the SEC, has been created by litigation under the antifraud rule. See, e.g., Cox, HiLlman \& LANGEVOORT, supra note 43, at 619-93. And causality, a feature in all private litigation, is shaped almost entirely by case precedents. An exception would be the Private Securities Litigation Reform Act (PSLRA) bounce-back rule. 
Rule 10b-5, and courts can be expected, as they have been in the past, to be sensitive to the expected burdens flowing from expansion of the antifraud provision. $^{56} \mathrm{~A}$ benefit of this approach is that it promotes reactions through changed business practices, and those consequential costs can be analyzed in future rulemaking.

\section{$\mathrm{V}$ \\ REgULATING BY PRINCIPLES AND SAFE HARBORS}

There are three pillars that enable the SEC to fulfill the goals of the federal securities laws: specific congressional directives, the broad rulemaking authority the SEC has to carry out the directives' objectives, and the authority of the SEC to enforce the statutes and rules committed to its stewardship. For example, the Securities Act of 1933 (the Securities Act) prohibits the offer or sale of a security unless a registration statement has been filed with the SEC; the Act further provides, however, numerous exemptions to this prohibition, the most famous being an offer or sale of a security "by an issuer not involving any public offering." ${ }^{57}$ And, the SEC enjoys a broad grant of authority to fulfill the prohibitions and define their exemptions.

Consider the operation of the private-offering exemption provided by Section 4(a)(2) of the Act: "transactions by an issuer not involving any public offering." ${ }^{, 58}$ The generality with which this exemption is expressed permits it to be understood as "principles-based," as distinct from finite and technical conditions to meet the exemption, which would be considered, at least in this article, to be "rules-based." Ambiguity with reference to a provision's scope is an inherent feature of a principles-based exemption and, in the case of the private offering exemption, the meaning was developed through SEC enforcement actions as well as administrative guidance provided through SEC announcements.

Ultimately, in 1982, the SEC, building on five decades of experience in both the courts and the administrative practice, greatly facilitated the aggregation of capital by resorting to the private-offering exemption through the adoption of Rule 506, a safe harbor for private offerings. ${ }^{59}$ Rule 506 embodies the codification of understandings and practices that have crept into the private offering lore over the years and that have made the exemptions more certain thanks to a high degree of specificity. The significance of Rule 506 begins by recognizing that more capital was raised in recent years through various exemptions from registration that are provided by the Securities Act than was

56. The classic illustration of this concern is Blue Chip Stamps v. Manor Drug Stores, 421 U.S. 723 (1975), conditioning private actions on the plaintiff being a purchaser or seller, for fear that otherwise cases would be difficult to dispose of before trial and that a loose-standing provision would lead to vexatious litigation.

57. 15 U.S.C. $\S 77 d(a)(2)(2012)$.

58. $I d$.

59. See 17 C.F.R. $§ 230.506$ (2014). 
raised by all registered public debt and equity offerings; the importance of Rule 506 in this tabulation is that it is the gateway for most exempt offerings. ${ }^{60}$

Another illustration of the tandem operation of a broadly based prohibition and a complementary safe harbor is the securities laws prohibition against manipulation of securities prices. In the 1950s, the SEC adopted a set of socalled "distribution rules," designed to proscribe purchases believed to be manipulative in connection with a distribution and to authorize stabilization of securities prices in connection with a distribution. ${ }^{61}$ The former rule broadly prohibited issuers and their representatives from purchasing issuers' shares during a distribution, unless the purchases conformed to the tightly drafted requirements that were to be deemed stabilizing in connection with public offerings carried out by underwriters. The authority for the rules was broadly founded on the enabling language of Sections 9 and 10(b) of the Exchange Act.

The distribution rules were not only broadly written but were also broadly interpreted by the SEC. For example, an issuer with outstanding securities convertible into or warrants exercisable for its common stock, was viewed to be engaged in an ongoing distribution of the common stock. ${ }^{62}$ The SEC's regulatory position was underscored when it initiated an enforcement action against Georgia-Pacific Corporation, arguing that its purchases of its own shares in connection with acquisition of other companies not only violated the distribution rule but also the antifraud provision, Rule $10 \mathrm{~b}-5 .^{63}$

At the heart of the SEC's case was that Georgia-Pacific had agreed to acquire several businesses, paying for each with shares of its own stock. The exact number of shares to be issued in each acquisition was to be determined by the New York Stock Exchange (NYSE) share price at certain points in time. The SEC argued that Georgia-Pacific's market purchases were undertaken to drive up the price of its shares so that fewer shares would have to be issued to affect each of the purchases. ${ }^{64}$ The case was ultimately settled, with GeorgiaPacific consenting to an injunction barring it from carrying out purchases for the purpose of creating actual or apparent active trading in its shares. ${ }^{65}$ The victory against Georgia-Pacific wetted the SEC's appetite for expanding the prohibition to like cases. Over the next decade, the SEC proposed and reproposed Rule 13e-2, which broadly proscribed open-market purchases that

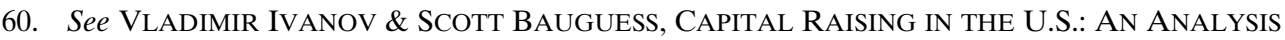
OF UNREGISTERED OFFERINGS USING THE REGULATION D EXEMPTION, 2009-2012, 8 Tbl.2, 9 Fig.4 (2013).

61. See Former Exchange Act Rule 10b-6. 17 C.F.R. § 240.10b-6 (1963).

62. See Lloyd H. Feller \& Mary Chamberlin, Issuer Repurchases, 17 REV. OF SEC. REg. 1, 2 (1984). On the scope of the meaning of distribution in the former distribution rule, see Nicholas Wolfson, Rule 10b-6: The Illusory Search of Certainty, 25 STAN. L. REV. 809 (1973).

63. See SEC v. Georgia-Pacific Corp., [1964-66 Transfer Binder] Fed. Sec. L. Rep. (CCH) II 91,680 (S.D.N.Y. Apr. 27, 1966).

64. See id. II 95,488.

65. See SEC v. Georgia-Pacific Corp., [1964-66 Transfer Binder] Fed. Sec. L. Rep. (CCH) II 91, 692 (S.D.N.Y. May 24, 1966). 
at least covered the practice prosecuted in Georgia-Pacific. ${ }^{66}$ Of interest in this article is that the Commission's proposed proscription occurred after it sought and obtained in the 1968 Williams Act amendments specific authority in Section 13(e) of the Exchange Act - that is, the authority to adopt rules with respect to reporting company purchases of their outstanding equity securities. ${ }^{67}$ Comments on the proposed rules were favorable; however, the reason the proposal enjoyed support was that, despite the proposed rule's breadth and new burdens, its overarching benefit was that the proposed rule was believed to reduce uncertainty with respect to issuer share repurchases. ${ }^{68}$

The 1980 national election changed the regulatory climate; this political shift was reflected with the demise of earlier proposed Rule $13 \mathrm{e}-2$ and the adoption of Rule 10b-18. ${ }^{69}$ Unlike the former route of broadly proscribing issuer repurchases, the newly adopted Rule 10b-18 was, in effect, a safe harbor that set forth clearly articulated conditions that, if met, rendered issuer repurchases immune from being deemed manipulative. Similar to the experience with the Rule 506 safe harbor described above, the Rule 10b-18 safe harbor became the beacon by which issuers today engage in open market purchases.

The preceding account shows that a principle can come through a statute, rule, or an enforcement order. The norm developed through whatever medium contains the principles that can inform later rulemaking. Where the statute clearly announces a principle and renders its violation enforceable, the SEC has a base upon which it can regulate not just through enforcement of the provision but also in a prudential way. A similar result can be achieved through a successful enforcement action. The very robust no-action letter regime and the less-formal conversations with SEC staff are each reflective of a good deal of prudential regulation in vast sectors of the federal securities laws. It is in these areas that customs have developed that frequently give rise to safe harbors. And the safe harbors are more than that; they become the manner for conducting business.

Thus, we should consider the two-step approach to regulation illustrated by the SEC's regulation of private offerings and issuer repurchases, whereby the first step is a broad principles-based prohibition, and the second step is development of a safe harbor from the principle, with such development being based on refinements that evolve through litigation. ${ }^{70}$ To be sure, this is a long-

66. See Purchases of Certain Equity Securities by the Issuer and Others, Exchange Act Release No. 17,222, Fed. Sec. L. Rep. (CCH) II 82,669 (Oct. 17, 1980) (re-proposing for the second time rules broadly proscribing issuer purchases); Revision of Proposed Rule 13e-2 and Amendment of Rule 10b-6 Under the Exchange Act, Exchange Act Release No. 10,539, Fed Sec. L. Rep. (CCH) II 79,600 (Dec. 6, 1973); Notice of Proposal to Adopt Rule 13e-2 and to Amend Rule 10b-6 Under the Securities Exchange Act, Exchange Act Release No. 8,930 (July 13, 1970) (proposing Rule 13e-2).

67. See 15 U.S.C. $\$ 78 \mathrm{~m}(\mathrm{e})$ (2012).

68. See Feller \& Chamberlin, supra note 62, at 4.

69. 17 C.F.R. $\$ 240.10$ b-18 (2014).

70. Many provisions of the securities laws are not proscriptive but enabling. But this is not a limitation on the iterative approach developed here. For example, the SEC's ability to act by enforcement and by protective safe harbors is not possible absent a rule identifying conduct as 
term strategy and one not well-suited to address market developments that occur rapidly and that need to be quickly addressed. Nonetheless, there are ample areas where market events permit regulation to evolve so as to benefit from the experiences of incremental steps forward. Rules 506 and 10b-18 stand witness to positive experiences provided by a lengthy gestation period.

Business Roundtable II concerns do not disappear by taking an approach that links principles-based proscription with safe harbor rules. There is some appeal to the argument that, since safe harbors are optional and provide a dispensation from a hard principle, a lighter review might be in order for the adoption of a safe harbor. This may well be the case, but safe harbors are nonetheless subject to the review standard. In Chamber of Commerce v. SEC, ${ }^{71}$ Judge Ginsburg, perhaps as a warm-up for his later opinion in Business Roundtable II, struck down an SEC-proposed safe harbor for investment advisors wishing to engage in a range of transactions that the Investment Company Act otherwise bars. Absent the safe harbor, the pathway for advisors wishing to engage in many common related-party transactions was to obtain approval of the SEC.

Chamber of Commerce arose from the SEC amending its existing safe harbor that permitted certain transactions by an advisor, but conditioned the dispensation on the mutual fund having an independent board chair, and a board whose members were at least seventy-five percent independent of the fund's advisor. The newly adopted safe harbor replaced one that only required that fifty percent of the directors be independent and made no provision for the board's chair to be independent. In the release adopting the safe harbor, the SEC stated that, because it did not have a reliable basis to know what

unlawful, because otherwise there is no enforceable principle. The illustration of this is Section 14(a)(2) authorizing the SEC to adopt rules regarding proxy access for the nomination of directors. See Securities Exchange Act of 1934, 15 U.S.C. § 78(n)(a)(2) (2012). There the SEC's foray into providing a very limited route for shareholder access to nominating directors was foiled by Business Roundtable II. Because the provision is only enabling there clearly is no enforceable principle absent a rule announcing the principle. At the same time, is it beyond question that it could be a material omission in failing to disclose in the company's proxy statement that a holder of fifteen percent of a reporting company's shares was rebuffed in suggesting a nominee to the board? Whether or not a court might be persuaded under the right set of facts that enough facts were alleged to survive a motion to dismiss, there still likely would be enough uncertainty among issuers to see the benefit of a safe harbor in the face of repeated efforts by activist shareholders to obtain board seats. The SEC could consider circling back to Section 14(a)(2) to clear the air a bit by adopting a safe harbor to potential Rule 14a-9 concerns that would provide protection to firms whose bylaws provided a means for activist access to the nominating process. This reaches a result distinguishable from Business Roundtable II since proxy access is not being imposed but is acting as an optional prophylaxis to possible alleged omissions in the proxy statement. Indeed, it was on just such reasoning that the SEC justified the shareholder proposal provision now embodied in Rule 14a-8 that allows stockholders meeting certain requirements to have their - a proposal they intend to introduce at an upcoming stockholder meeting included on management's solicitation materials. The SEC justified Rule $14 \mathrm{a}-8$ on the grounds that it would be a material misrepresentation for management, as management customarily does with its own solicitations, to be granted a proxy to vote on any matter that may be introduced at the upcoming annual meeting, if management did not in connection with such request identify a proposal that it was aware would be introduced at the meeting that management opposed.

71. 412 F.3d 133 (D.C. Cir. 2005). 
procedures funds would pursue to recruit and maintain additional independent directors so as to raise the percentage from fifty to seventy-five percent, it was difficult for the SEC to determine the costs associated with the proposal. This difficulty was rejected; the court concluded that such difficulty "does not excuse the Commission from its statutory obligation to determine, as best it can, the economic implications of the rule it has proposed." 72 The Commission was similarly faulted for not attempting to estimate what, if any, costs might flow from the board chair being independent, were such a chairman then to introduce new staffing needs. ${ }^{73}$ Adding further weight to its rejection, the Commission was faulted in adopting the safe harbor for not considering disclosure, the more familiar mechanism for securities regulation. ${ }^{74}$

Chamber of Commerce, however, casts only a minor cloud over the two-step process advanced here. For years, because the fund industry had enjoyed a safe harbor for otherwise prohibited activities that was conditioned on a fund's board meeting a fifty-percent independence requirement, the adoption of the safe harbor can easily be seen as action that is introducing more stringent regulation than before, rather than as providing both certainty and dispensation, as was the case with Rules 506 and 10b-18. Thus, in Chamber of Commerce, the safe harbor was being narrowed with the effect that commercial flexibility was being constrained, not liberated, from an overarching prohibition. To be sure, regulated parties can still challenge a newly minted safe harbor, no doubt seeking greater liberality, but they do so with a healthy respect that the SEC is not required to act. This political calculus no doubt explains the mild support that proposed Rule $13 \mathrm{e}-2$ received: it is not the best rule for the regulated, but it is better than the likely alternatives.

VI

MEAN REVERTING JURISPRUDENCE?

In recent years, the SEC has certainly incurred reversals before the D.C. Circuit. But it is the stridency and sweeping mandate of Business Roundtable II that most becalms the SEC's regulatory trajectory. Elsewhere I have made the case that, not only was Judge Ginsburg's reasoning inconsistent with the

\section{Id. at 143 .}

73. The court wrote:

Although the Commission may not have been able to estimate the aggregate costs of the mutual fund industry of additional staff because it did not know what percentage of funds with independent chairman would incur that costs, it readily could have estimated the costs of an individual fund, which estimate would be pertinent to its assessment of the effect the condition would have on efficiency and competition, if not upon capital formation .... [U]ncertainty may limit what the Commission can do, but it does not excuse the Commission from its statutory obligation to do what it can to apprise itself-and hence the public and the Congress - of the economic consequences of a proposed regulation before it decides whether to adopt the measure.

Id. at 144 .

74. See id. ("[T]he disclosure alternative was neither frivolous nor out of bounds and the Commission therefore had an obligation to consider it."). 
language and history of the SEC's review standard, it is also dramatically inconsistent with the Supreme Court precedent, most of which was not referenced at all in Business Roundtable II. Indeed, the major body of precedent Ginsburg invoked was his earlier decision in Chamber of Commerce. $^{75}$

In turn, Chamber of Commerce relied on the D.C. Circuit's earlier decision, Public Citizen v. Federal Motor Carrier Safety Administration ${ }^{76}$ which struck down an agency rule limiting the number of hours commercial drivers could work, reasoning that the agency failed, as required by its enabling act, to craft a rule that would "ensure that ... the operation of commercial motor vehicles does not have a deleterious effect on the physical condition of the operators." The review standard guiding Public Citizen clearly mandated cost-benefit analysis, and the opinion did observe that there were possible infirmities with such analysis in connection with the rule; however, this was dicta since the analysis clearly found that the agency "wholly failed to comply with this specific statutory requirement [of ensuring no deleterious effects]." ${ }^{18}$ Thus, the error that Ginsburg committed was seriously misreading Public Citizen when deciding Chamber of Commerce and then magnifying that mistake in Business Roundtable II.

Public Citizen, while referencing that the agency's adopted rule might well have been faulted for failing to address the statute's express requirement that rules be supported by cost-benefit analysis, did not do so. Of note is that the author of Public Citizen was Judge Sentelle, who also authored American Equity Investment Life Insurance Co. v. SEC ${ }^{79}$ which vacated a rule that had the effect of requiring indexed annuity options to be registered with the SEC. The SEC had initiated the regulatory change because it believed that definitively characterizing indexed annuity options as securities would "bring about clarity in what [had] been an uncertain area of law." ${ }^{80}$ Writing for the panel, Judge Sentelle focused on the incompleteness of the SEC's analysis and not on the presence or absence of cost-benefit analysis; the court looked at the SEC's findings that the rule change would favorably impact "efficiency," "competition," and "capital formation." The court concluded that the SEC did "not disclose a reasoned basis for its conclusion that Rule 151A would increase competition" " and that the "SEC's failure to analyze the efficiency of the existing state law regime renders arbitrary and capricious the SEC's judgment that applying federal securities law would increase efficiency." 82 Thus, Judge

75. 412 F.3d 133 (D.C. Cir. 2005).

76. 374 F.3d 1209 (D.C. Cir. 2004).

77. Id. at 1216 (citing 49 U.S.C. § 31136(a)(4) (2006)).

78. Id.

79. 613 F.3d 166 (D.C. Cir. 2010).

80. Id. at 177 (quoting Indexed Annuities and Certain Other Insurance Contracts, Securities Act Rel. No. 8996, 74 Fed. Reg. 3138, 3171 (Jan. 16, 2009)).

81. Id. (emphasis added).

82. Id. at 179 (emphasis added). 
Sentelle applied bedrock administrative law embodied in Motor Vehicle Manufacturers Association v. State Farm Mutual Automobile Co. ${ }^{83}$ holding that when an agency finds its rule is supported by cost-benefit analysis that is not supported by a reasoned analysis, the rule will be vacated as being arbitrarily and capriciously adopted, even though the enabling legislation does not mandate cost-benefit analysis. Hence, in American Equity, the agency's action was vulnerable because it was not able to support its conclusions that providing clarity by rendering indexed annuity options a security would enhance efficiency, competition, and capital formation any more than a rule that clarified that this product was not a security.

Judge Sentelle most recently entered the regulatory review scene in Investment Company Institute v. CFTC. ${ }^{84}$ The regulatory quilt for swap transactions changed dramatically following the financial crisis of 2008 and the ensuing passage of the Dodd-Frank Wall Street Reform and Consumer Protection Act of 2010. Dodd-Frank authorized the SEC and CFTC to regulate most swaps, thereby reversing the deregulatory steps of the Commodity Futures Modernization Act of 2000. Thus, the CFTC, earlier in reliance on the 2000 legislation, had removed regulated investment companies from being deemed commodity pool operators; the rule challenged in Investment Company Institute returned matters pretty much to where they were before 2000. As a consequence, regulated investment companies that carried on activities that rendered them commodity pool operators would be required not only to provide certain investor fraud protections, but also to register with the CFTC and to provide it periodically with certified reports bearing on their transactions in swaps.

Judge Sentelle stated, "As a reviewing court, '[o]ur role is to determine whether the [agency's] decision was based on a consideration of the relevant factors and whether there has been a clear error of judgment." ${ }^{85}$ Importantly, this standard was stated in the context of the court's review of the CFTC's requirement to "consider the costs and benefits" of a rule being adopted. The court emphasized that the CFTC closely considered whether information that it sought regarding the fund's operations of commodity pools was otherwise available, and concluded that it was not. The CFTC's close consideration of these concerns allowed Judge Sentelle to distinguish the present regulatory effort from earlier efforts by the SEC in American Equity where the SEC baldly dismissed alternative regulatory approaches. For example, Judge Sentelle observed that, in American Equity, the SEC made no effort in considering whether state regulation of indexed annuities provided the clarity and protection the SEC believed would flow from its new Rule $151 \mathrm{~A} .{ }^{86}$

83. 463 U.S. $29,54-57$ (1983).

84. 720 F.3d 370 (D.C. Cir. 2013).

85. Id. at 377 (quoting State Farm, 463 U.S. at 43).

86. See id. at 378 ("'CFTC did consider whether RICs were otherwise regulated, and concluded that CFTC regulation was necessary' despite the existing SEC regime." (quoting Investment Company 
Despite operating under a review standard that calls for consideration of costs and benefits, and a standard that also lists multiple factors to be so considered, the court held that the CFTC was not required to calculate the costs incident to future regulations that were as-of-yet unknown. ${ }^{87}$ Thus, if the current action is the first of likely several future iterative regulatory steps, the calculus that is required is that incident to the initial step, not a subsequent one. Indeed, Investment Company Institute is welcoming to iterative regulation; it openly approved of the need for the CFTC to compel registration and regular reporting as a necessary initial step toward formulation of regulatory steps to implement the congressional mandate. ${ }^{88}$ Later, the court showed additional sympathy for the regulatory agency by holding that agencies are not required to measure the immeasurable. ${ }^{89}$ This was in response to the appellants' complaint that the agency failed under the review standard because it had not placed a "precise number" on the benefits that data collection would have in preventing future financial crises; instead, the CFTC met the standard by discussing the unquantifiable benefits. ${ }^{90}$ Indeed, Judge Sentelle concluded that the CFTC is not subject, as some agencies are, to producing rigorous quantitative analysis in support of its regulations. ${ }^{91}$

\section{VII}

\section{CONCLUSION}

Financial market regulation is a complex undertaking, and unintended consequences lurk behind ever well-meaning regulatory effort. The CFTC's steps toward bringing regulated investment companies that are commodity pool operators were no doubt taken with trepidation flowing not only from a host of unknowns, but also from the reality that sweeping regulatory directives other than those incident to information gathering would be difficult to achieve. Thus, the understanding and nurturing hand the D.C. Circuit most recently extended in Investment Company Institute is likely more reflective of understanding the challenge faced by the regulator than it is of blowing a new proregulatory wind across America. The sensitivity that Investment Company Institute reflects minimally stands in stark contrast to the quixotic harangue of Business Roundtable II. Surely there are better moorings for the regulatory state with the former than the latter. Thus, iterative regulation, in which regulatory goals are

Institute v. CFTC, 891 F. Supp. 2d at 217 (D.D.C. 2013))).

87. See id. ("Nothing prohibits federal agencies from moving in an incremental manner." (quoting FCC v. Fox Television Stations, Inc., 556 U.S. 502, 522 (2009) (Fox Television))).

88. See id. at 380. The CFTC also argued that no commenters on its proposed rule provided data that could be considered a substitute for what was sought by the rule's register-and-report requirement.

89. See id. at 379 (holding that agencies are not required to adduce empirical data that cannot be obtained (citing Fox Television, 556 U.S. at 519)).

90. Id.

91. See id. (holding that the agency is required to produce not only quantitative and qualitative assessments of the rule's costs and benefits but also estimates of the rule's impact on the nation's economy (citing American Financial Services Ass'n v. FTC, 767 F.2d 957, 986 (D.C. Cir. 1985))). 
achieved in stages, has much for which to commend itself, and Investment Company Institute provides support for this strategy.

By far the approach most within reach and worthy of consideration is that whenever regulation is considered it is advisable to do so incrementally, with the level being dictated by the breadth and complexity of the area to be regulated. Thoughtful regulation requires a good deal of insight into the likely consequences of the regulations. Investment Company Institute provides encouraging support not only for an iterative approach but also for the initial measured steps in pursuing an iterative approach; but this reflects the understanding that the regulator lacks Cassandra-like vision of the future to undertake reliable analysis of the burdens and benefits of a particular regulatory initiative. It is here that staged regulation, continuing the incremental approach, can build a compelling case to support the rule by demonstrating how evidence gathered at each stage informs the agency how to next proceed, including tweaking of its past initiatives.

As developed above, iterative regulation has worked well for the SEC when a securities statute or regulation announces a regulatory principle. Enforcement and experience gained under such a principle can inform the development of safe harbors. Thus, adoption and refinement of safe harbors are iterative, as is the more informal SEC no-action letter process. It would also be useful throughout the process to demonstrate how experience gained has enabled the agency, consistent with its presumed expertise, to adapt its rules so as to reduce their burdens on the regulated while increasing their expected benefits. Thus, agency initiatives to develop information regarding experiences of the regulated under a principle, safe harbor, or regulation obviously can inform future rulemaking.

Another key feature is sensitivity to compliance costs' disproportionate effect on smaller companies. Thus, through scaling regulation, the SEC can underscore its commitment to meeting the review standard that calls on it to consider investor protection against efficiency, competition, and capital formation. To be sure, as discussed earlier, with financial regulation it will be difficult, if not impossible, to disentangle a particular initiative from other forces. With respect to this concern, decisions such as Investment Company Institute embody a reassuring perspective, as the emphasis is on the process, not the precision, by which the analysis is undertaken. Iterative regulation will yield less speculation surrounding the inputs into that process than if regulation occurred in a noniterative fashion. 